\title{
STRESS AMONG MEDICAL STUDENTS - A GLOBAL CONCERN
}

Stress is any exasperating and infuriating "emotional experience accompanied by predictable biochemical, physiological, and behavioral changes [1]." At many occasions, stress can be useful at times, bring into being a boost that offers the drive and energy to help individuals get through situations such as examinations or work deadlines. Nevertheless, a life-threatening amount of stress can have health concerns and negatively upset the immune, cardiovascular, neuroendocrine, and central nervous systems [2]. The conservation of life is completely and strictly in need of protection of human internal setting and ambience that constantly faces several new hazardous environments [3]. Later, it was called this homeostasis [4]. The term stress to personify any upshots that extremely creep up homeostasis. The real or apparent intimidation to an organism is referred to as the stressor and the reaction to the stressor is called the stress response. Even though stress responses go forward as adaptive processes, and it was perceived that austere, sustained stress repeatedly leads to tissue damage and disease [5]. Quite a few studies reported that medical students very often suffer from stress and disturb sleep pattern [6-14]. Furthermore, quite a lot of studies also described that academic issues generate the major amount of stress among medical students [15-18]. One study reported that there is a reasonable of negative $(-0.583)$ and significant $(p<0.01)$ association concerning academic performance and sources of stress. Correspondingly, there is modest negative $(-0.478)$ and significant $(p<0.01)$ relationship between academic performance and levels of stress [19]. Another Malaysian study revealed that students studying medicine and health sciences had the highest mean stress score of $1051.8 \pm 342.29$. The same study also found that stress is significantly associated with academic achievement $(\mathrm{p}=0)$. The relationship between stress and academic achievement is negative and weak $(\mathrm{r}=-0.195)$ [20]. Furthermore, one Ethiopian study also found similarly that stress was significantly $(\mathrm{p}=0.001)$ but negatively $(\mathrm{r}=-0.273)$ correlated with academic attainment [21]. Medical educationists, curriculum developer, medical authority, lecturers, policy makers, and other stakeholders must need to address the issue of stress among medical students individually as the delinquent will be a different scenario for every single medical school. Thereafter, medical school can have definite improvement to produce more community-oriented holistic and rational prescriber for our planet.

MAINUL HAQUE*

Unit of Pharmacology, Faculty of Medicine and Defence Health, Universiti Pertahanan Nasional Malaysia (National Defence University of Malaysia)

Kem Sungai Besi, 57000 Kuala Lumpur, Malaysia. Email: runurono@gmail.com

Received: 24 May 2017, Revised and Accepted: 10 June 2017

\section{REFERENCES}

1. Baum A. Stress, intrusive imagery, and chronic distress. Health Psychol 1990;9(6):653-75.

2. Anderson NB. Levels of analysis in health science: A framework for integrating socio-behavioral and biomedical research. Ann N Y Acad Sci 1998;840:563-76.
3. Bernard C. An Introduction to the Study of Experimental Medicine. New York, USA: Dover Publications; 1957.

4. Cannon WB. Bodily Changes in Pain, Hunger, Fear and Rage. $2^{\text {nd }} e d$. New York: Appleton; 1929.

5. Selye H. The Stress of Life. New York: McGraw-Hill; 1956.

6. Goyal P, Upadhyah AA, Pandit DP, Sharma D, Howale D. A study of stress, stressors, and coping strategies among students of a newly established medical college in South Gujarat. Natl J Physiol Pharm Pharmacol 2016;6(6):604-11.

7. Anandhalakshmi S, Sahityan V, Thilipkumar G, Saravanan A, Thirunavukarasu M. Perceived stress and sources of stress among firstyear medical undergraduate students in a private medical college-Tamil Nadu. Natl J Physiol Pharm Pharmacol 2016;6(1):9-14.

8. Mehta K, Kaur S, Girgla KK, Kaur P, Kaur H. A study of mental distress in medical students. Natl J Physiol Pharm Pharmacol 2015;5(3):190-4.

9. Eva EO, Islam MZ, Mosaddek AS, Rahman MF, Rozario RJ, Iftekhar AF, et al. Prevalence of stress among medical students: A comparative study between public and private medical schools in Bangladesh. BMC Res Notes 2015;8:327.

10. Salam A, Rabeya Y, Bakar SM, Haque M. Stress among medical students in Malaysia: A systematic review of literatures. Int Med J 2013;20(6):649-55.

11. Rahman NI, Ismail SB, Seman TN, Rosli NF, Jusoh SA, Dali WP, et al. Stress among preclinical medical students of University Sultan Zainal Abidin. J Appl Pharm Sci 2013;3(11):76-81.

12. Rahman NI, Ismail SB, Ali RM, Alattraqchi AG, Dali WP, Umar BU, et al. Stress among first batch of MBBS students of faculty of medicine and health sciences, Universiti Sultan Zainal Abidin, Malaysia: When final professional examination is knocking the door. Int Med J 2015;22(4):254-9.

13. Unnikrishnan B, Darshan BB, Kulkarni V, Thapar R, Mithra PO, Kumar N, et al. Association of emotional intelligence with academic performance among medical students in South India. Asian J Pharm Clin Res 2015;8(2):300-2.

14. Mishra T, Mohapatra D, Behera M, Mishra S. Association between short sleep duration and obesity in medical students. Asian J Pharm Clin Res 2017;10(1):242-4.

15. Ismail S, Rahman NI, Mohamad N, Jusoh NM, Hood AI, Arif LA, et al. Preference of teaching and learning methods in a new medical school of Malaysia. J Appl Pharm Sci 2014;4(2):48-55.

16. Rahman NI, Aziz AA, Zulkifli Z, Haj MA, Nasir FH, Pergalathan S, et al. Perceptions of students in different phases of medical education of the educational environment: Universiti Sultan Zainal Abidin. Adv Med Educ Pract 2015;6:211-22.

17. Mohsena M, Debsarma S, Haque M. Determining the quality of educational climate in a private medical college in Bangladesh via the 'dundee ready education environment measure' instrument. J Young Pharm 2016;8(3):266-74.

18. Haque M, Zulkifli Z, Nasir FH, Majumder MA, Yusoff MS, Mostafa A, et al. Perception of tomorrow's health-care connoisseur and frontrunners of their educational environment utilizing DREEM inventory in Bahasa Melayu version, the native language of Malaysia. Acad Manag J 2017;10(5):361-72.

19. Sohail N. Stress and academic performance among medical students. J Coll Phys Surg Pak 2013;23(1):67-71.

20. Elias H, Ping WS, Abdullah MC. Stress and academic achievement among undergraduate students in university Putra Malaysia. Proc Soc Behav Sci 2011;29;646-55.

21. Melaku L, Mossie A, Negash A. Stress among medical students and its association with substance use and academic performance. J Biomed Educ 2015;2015:Article ID: 149509, 1-9. 